Proceedings of the 2018 International Scientific Conference 'Economic Sciences for Agribusiness and Rural Economy' No 2, Warsaw, 7-8 June 2018, pp. 144-153

\title{
COSTS OF VINEYARDS PRODUCTION IN SELECTED EU COUNTRIES IN THE PERIOD 2004-2015
}

\author{
Tadeusz Filipiak, $\mathrm{PhD}^{1}$; Mariusz Maciejczak, $\mathrm{PhD}^{2}$
}

Faculty of Economic Sciences, Warsaw University of Life Sciences - SGGW

\begin{abstract}
The aim of the research was to determine the production costs in farms specializing in viticulture in the selected European Union countries in the period 2004-2015. It was found that there was a large variation in terms of the structure of production costs. In the analysed period, the majority of countries recorded an increase in total costs per 1 ha, which was mostly due to the year by year increase of the direct costs. In direct costs the plant protection had the largest share, followed by fertilization costs, while the lowest were the costs of pruning. The share of indirect costs in total costs was relatively high and on EU average reached $82 \%$.
\end{abstract}

Keywords: cost of production, specialist vineyards, FADN, European Union

JEL codes: Q12, D24

\section{INTRODUCTION}

Commercial entities should conduct their businesses in such a way that are profitable. As noted by Latruffe (2010) agricultural producers often have no influence on the prices of their products, as they are shaped by the market, but they have a decisive influence on production costs. Therefore, in order to build a competitive advantage, it is important to properly and rationally bear the costs of running an agricultural business (Sobczyński and Stefko, 2011).

Activities aimed at building a competitive advantage and creating adequate cost related strategies refer to many branches of the agricultural sector, but they are particularly important for the wine sector in the European Union (EU). The wine sector, including viticulture production, plays a major role in many European countries, especially with the favourable conditions for running such production due to climatic and soil conditions as well as because of centuries-old tradition. However, as emphasized by Filipiak and Maciejczak (2018) achieving income from a farm growing vines for wine at the parity level does not determine the competitive capacity of a farm in the EU farms. This is largely due to significant variations and a relatively low level of costs, in particular wage labour costs.

According to the review of the literature, viticultural farms are influenced by many factors affecting the increase or reduction of the production costs. Sgroi et al. (2014) indicates that for many wine farms in Italy, the reduction of production costs is the only way to gain a competitive advantage. Introducing process innovations, despite the periodic increase in costs, allows to improve the cost position by lowering costs and increasing profit. On the other hand, Delord

${ }^{1}$ Corresponding author: Nowoursynowska 166,02-787 Warsaw, Poland, tadeusz_filipiak@sggw.pl, +4822 5934235

${ }^{2}$ Corresponding author: Nowoursynowska 166, 02-787 Warsaw, Poland, mariusz_maciejczak@sggw.pl, +4822 5934235 
et al. (2015) showed that in France the size of the farm had a small impact on economic performance. The yield of a farm growing grapes is only slightly dependent on their size. Differences in profitability between farms result from variability in the sale price of wine. These differences relate to the location and designation of origin (Protected Designation of Origin - PDO), i.e. under the influence of supply control and its potential, area and resources used for management in the countries and regions of the Protected Nomenclature of Origin. Maciejczak (2017) argues that the climate change conditions and their changes are important factors that could influence the economic performance of viticultural production in Poland, which as a the EU wine country takes dynamic actions to re-establish and develop viticutural and wine production.

Thus, bearing in mind that the wine sector plays an important role in the economies of many EU Member States, both these with long wine production tradition and those being relatively new on the market as well as considering the problems of profitability of viticulture indicated by many authors (Umbreziova and Hrda, 2014; Toth and Vegvari, 2015), the question arises about the cost of production in wine farms in the EU countries, especially with regard to their structure and size.

\section{Objectives and methods}

The aim of the research was to determine the production costs in farms specializing in viticulture in selected European Union countries in the period 2004-2015. The study features the characteristics of wine farms in selected EU countries, then the level and structure of production costs, including direct costs and indirect costs were determined. The undertaken approach to perform such analysis is well established in the literature and focuses on relations of the costs to the production, being direct or indirect (Goraj and Manko, 2004; Kondraszuk, 2012). In crop production, including in viticulture, direct costs cover: costs of cuttings, costs of organic and mineral fertilizers, costs of plant protection and other specialized cultivation costs. Indirect costs include: general production costs (maintenance of buildings and machinery, energy, external services and other general production costs, such as water, insurance, etc.), depreciation costs, taxes and costs of external factors (wage labour, rent and interest). Individual types of costs were calculated per 1 ha of arable land, so as to make a comparative analysis of viticulture on farms. It is important however to notice that the analysis of specialist vineyards with regard to their costs of production might significantly vary due to many factors, including roodstock and variety, age of plants, the scale of pruning, as well as biotic and factors, etc. Therefore the comparability analysis are difficult due to unification. To overcome such difficulties the European Farm Data Accountancy Network provides the solution for more credible economic analysis.

The research cover farms specializing in viticulture participating in the European FADN system. The time range cover the years 2004-2015. Within the analysed period, the data was available for 14 countries, including: Austria, Bulgaria, Croatia, Cyprus, the Czech Republic, Greece, France, Spain, Germany, Portugal, Romania, Slovenia, Hungary and Italy. Farms specializing in viticulture are classified according to the FADN typology TF8 to type 3 - specialist vineyards.

The article uses methods of descriptive statistics, including the absolute and relative dynamics of changes using linear ${ }^{3}$ and exponential ${ }^{4}$ regression $^{-}$ analysis. In horizontal comparisons, due to high volatility, averages over the entire multi-year and threeyear averages were applied.

\footnotetext{
${ }^{3}$ The regression coefficient was calculated based on a linear function in Excel using the REGLINP formula. It is the slope of the regression line and represents the average increase in the value of the dependent variable assuming an increase in the value of the independent variable by 1 unit (time variable $-t$ ).

${ }^{4}$ The average annual change was also calculated based on the exponential function in Excel thanks to the formula of the REGEXPP function. In regression analysis, the function calculates the exponential curve that best fits the data and returns an array of values describing this curve. The function returns an array of values, so it must be entered in the form of an array formula. The curve equation is: $y=\left(b \cdot\left(m_{1} \wedge x_{1}\right) \cdot\left(m_{2} \wedge x_{2}\right) \cdot{ }_{-}\right)$.
} 
Proceedings of the 2018 International Scientific Conference 'Economic Sciences for Agribusiness and Rural Economy' No 2, Warsaw, 7-8 June 2018, pp. 144-153

\section{RESOURCES OF SPECIALIST VINEYARDS FARMS}

In the period 2004-2015, the largest viticultural farms were observed in Bulgaria (on average 25.7 ha of UAA), in France (24.4 ha of UAA) and in Spain (21.7 ha of UAA). On the other hand, the smallest farms specializing in viticulture were in Cyprus (on average about 4.0 ha of UAA), on Croatia (4.3 ha of UAA), in Slovenia (approx. 4.5 ha of UAA) and in Greece (4.7 ha of UAA). The resources of viticultural farms in selected EU countries in the years 2004-2015 are presented in Table 1 .

In the analysed period, the largest increase in farm area in relative terms was recorded on Spanish farms (annual average of more than 2.9\%), Hungarian (2.7\%), German (2.4\%), Italian (almost 2.3\%) and Portuguese farms $(2.1 \%)$. The decrease in the area of surveyed farms was recorded in Czech farms (on average by $9.4 \%$ ), Austrian (by $-6.5 \%$ ), Romanian (almost 5\%) and Cypriot (by-2.9\%). In absolute terms, the largest increase was recorded in Spanish farms (on average by 0.6 ha of UAA), Bulgarian (by 0.3 ha of UAA) and German (by 0.28 ha of UAA). The largest decrease in absolute terms was recorded in Czech farms (on average annually by -1.39 ha of UAA) and Austrian farms (by -1.16 ha of UAA). Practically at the same level in the analysed period, the UAA occurred on Croatian, French and Greek farms.

In the analysed period, the largest labour resources per 1 ha of UAA occurred in Croatian farms $(0.43$ AWU per 1 ha UA on average), Slovenian (0.42 AWU per 1 ha UAA), Romanian ( 0.3 AWU per 1 ha UAA) and Cypriot (0.28 AWU per 1 ha of UAA). The smallest work resources per 1 ha of UAA were on Spanish farms (0.07 AWU per 1 ha UAA), Austrian farms (0.10 AWU per 1 ha UAA) and French farms (0.11 AWU per 1 ha UAA). In the years 2004-2015, the increase in labour outlays per 1 ha of arable land was observed in Austrian farms (on average by $7.5 \%$ ),

Table 1. Main production factors of specialist vineyards in selected EU countries in the years 2004-2014

\begin{tabular}{|c|c|c|c|c|c|c|c|c|}
\hline \multirow[t]{2}{*}{ Specification } & \multirow[t]{2}{*}{ Country } & $\begin{array}{l}2004- \\
-2006\end{array}$ & $\begin{array}{l}2007- \\
-2009\end{array}$ & $\begin{array}{l}2010 \\
-2012\end{array}$ & $\begin{array}{l}2013- \\
-2015\end{array}$ & $\begin{array}{c}\text { Average } \\
2004- \\
-2015\end{array}$ & \multicolumn{2}{|c|}{$\begin{array}{c}\text { Average } \\
\text { annual change }\end{array}$} \\
\hline & & \multicolumn{6}{|c|}{ absolute values } & $\%$ \\
\hline \multirow{15}{*}{$\begin{array}{l}\text { Area of } \\
\text { utilised } \\
\text { agricultural } \\
\text { area } \\
\text { (ha) }\end{array}$} & (BGR) Bulgaria* & - & 25.04 & 24.96 & 27.12 & 25.71 & 0.34 & 1.24 \\
\hline & (CYP) Cyprus* & 4.75 & 3.90 & 3.72 & 3.67 & 4.01 & -0.13 & -2.92 \\
\hline & (CZE) Czech Republic & 20.52 & 21.71 & 9.36 & 8.66 & 15.06 & -1.39 & -9.40 \\
\hline & (DEU) Germany & 10.60 & 11.13 & 13.04 & 12.79 & 11.89 & 0.28 & 2.43 \\
\hline & (ELL) Greece & 4.68 & 4.49 & 4.36 & 5.12 & 4.66 & 0.05 & 0.81 \\
\hline & (ESP) Spain & 17.41 & 22.48 & 24.21 & 22.78 & 21.72 & 0.60 & 2.92 \\
\hline & (FRA) France & 24.81 & 24.42 & 24.12 & 24.39 & 24.44 & -0.05 & -0.22 \\
\hline & (HRV) Croatia* & - & - & - & 4.33 & 4.33 & 0.00 & -0.11 \\
\hline & $(\mathrm{HUN})$ Hungary & 8.77 & 9.82 & 10.76 & 11.33 & 10.17 & 0.28 & 2.75 \\
\hline & (ITA) Italy & 7.16 & 7.81 & 8.18 & 8.89 & 8.01 & 0.18 & 2.29 \\
\hline & (OST) Austria & 23.24 & 17.77 & 14.03 & 12.72 & 16.94 & -1.16 & -6.54 \\
\hline & (POR) Portugal & 8.96 & 9.75 & 10.38 & 10.75 & 9.96 & 0.21 & 2.10 \\
\hline & (ROU) Romania* & - & 9.86 & 10.45 & 6.92 & 9.08 & -0.37 & -4.95 \\
\hline & (SVN) Slovenia* & 4.66 & 5.06 & 4.32 & 4.19 & 4.54 & -0.08 & -1.75 \\
\hline & (EU) European Union & 13.31 & 14.05 & 13.85 & 14.16 & 13.84 & 0.08 & 0.57 \\
\hline
\end{tabular}


Proceedings of the 2018 International Scientific Conference 'Economic Sciences for Agribusiness and Rural Economy' No 2, Warsaw, 7-8 June 2018, pp. 144-153

Table 1 - cont.

\begin{tabular}{|c|c|c|c|c|c|c|c|c|}
\hline \multirow[t]{2}{*}{ Specification } & \multirow[t]{2}{*}{ Country } & $\begin{array}{l}2004- \\
-2006\end{array}$ & $\begin{array}{l}2007- \\
-2009\end{array}$ & $\begin{array}{l}2010 \\
-2012\end{array}$ & $\begin{array}{l}2013- \\
-2015\end{array}$ & $\begin{array}{l}\text { Average } \\
2004- \\
-2015\end{array}$ & \multicolumn{2}{|c|}{$\begin{array}{c}\text { Average } \\
\text { annual change }\end{array}$} \\
\hline & & \multicolumn{6}{|c|}{ absolute values } & $\%$ \\
\hline \multirow{15}{*}{$\begin{array}{l}\text { Total labour } \\
\text { input } \\
\text { (AWU/ha } \\
\text { UAA) }\end{array}$} & (BGR) Bulgaria* & - & 0.27 & 0.22 & 0.17 & 0.22 & -0.10 & -7.1 \\
\hline & (CYP) Cyprus* & 0.21 & 0.26 & 0.34 & 0.35 & 0.28 & 0.15 & 7.2 \\
\hline & (CZE) Czech Republic & 0.15 & 0.18 & 0.21 & 0.24 & 0.19 & 0.08 & 4.5 \\
\hline & (DEU) Germany & 0.22 & 0.21 & 0.19 & 0.20 & 0.21 & -0.02 & -1.6 \\
\hline & (ELL) Greece & 0.28 & 0.29 & 0.26 & 0.19 & 0.25 & -0.09 & -4.2 \\
\hline & (ESP) Spain & 0.08 & 0.06 & 0.06 & 0.06 & 0.07 & -0.01 & -2.1 \\
\hline & (FRA) France & 0.11 & 0.11 & 0.11 & 0.12 & 0.11 & 0.01 & 1.2 \\
\hline & (HRV) Croatia* & - & - & - & 0.43 & 0.43 & 0.00 & -4.6 \\
\hline & (HUN) Hungary & 0.22 & 0.18 & 0.19 & 0.20 & 0.20 & -0.02 & -0.9 \\
\hline & (ITA) Italy & 0.18 & 0.16 & 0.15 & 0.14 & 0.16 & -0.04 & -2.9 \\
\hline & (OST) Austria & 0.07 & 0.09 & 0.11 & 0.14 & 0.10 & 0.07 & 7.5 \\
\hline & (POR) Portugal & 0.21 & 0.18 & 0.17 & 0.17 & 0.18 & -0.04 & -2.4 \\
\hline & (ROU) Romania* & & 0.22 & 0.24 & 0.32 & 0.30 & 0.32 & -0.6 \\
\hline & (SVN) Slovenia* & 0.45 & 0.54 & 0.50 & 0.35 & 0.42 & -0.10 & -2.2 \\
\hline & (EU) European Union & 0.13 & 0.12 & 0.12 & 0.12 & 0.12 & 0.00 & -0.4 \\
\hline \multirow{15}{*}{$\begin{array}{l}\text { Total assets } \\
\text { (EUR/ha } \\
\text { UAA) }\end{array}$} & (BGR) Bulgaria* & - & 10.69 & 12.34 & 11.16 & 11.40 & 0.16 & 1.7 \\
\hline & (CYP) Cyprus* & 28.54 & 32.83 & 61.02 & 35.89 & 39.57 & 0.18 & 3.9 \\
\hline & (CZE) Czech Republic & 13.16 & 15.43 & 24.80 & 55.56 & 27.24 & 5.43 & 14.5 \\
\hline & (DEU) Germany & 44.78 & 46.42 & 41.15 & 45.57 & 44.48 & -0.18 & -0.3 \\
\hline & (ELL) Greece & 19.46 & 22.13 & 20.92 & 20.13 & 20.66 & -0.29 & 0.1 \\
\hline & (ESP) Spain & 10.13 & 9.68 & 9.07 & 9.96 & 9.71 & 0.04 & -0.3 \\
\hline & (FRA) France & 20.20 & 22.48 & 24.40 & 25.39 & 23.12 & 0.51 & 2.6 \\
\hline & (HRV) Croatia* & - & - & - & 54.80 & 54.80 & -4.81 & -8.8 \\
\hline & (HUN) Hungary & 16.25 & 14.57 & 17.97 & 18.97 & 16.94 & 0.37 & 2.1 \\
\hline & (ITA) Italy & 37.82 & 39.52 & 45.56 & 47.15 & 42.51 & 1.07 & 2.5 \\
\hline & (OST) Austria & 13.09 & 17.35 & 21.35 & 25.79 & 19.39 & 1.39 & 7.5 \\
\hline & (POR) Portugal & 11.29 & 11.58 & 14.78 & 17.22 & 13.72 & 0.69 & 4.9 \\
\hline & (ROU) Romania* & - & 20.42 & 9.95 & 14.29 & 14.89 & -0.80 & -4.0 \\
\hline & (SVN) Slovenia* & 39.74 & 36.09 & 48.73 & 57.61 & 46.07 & 2.61 & 5.6 \\
\hline & (EU) European Union & 21.26 & 22.44 & 25.53 & 27.04 & 24.06 & 0.67 & 2.8 \\
\hline
\end{tabular}

* Data for Slovenia since 2005, for Bulgaria and Romania since 2007 and Croatia since 2013 (entry into the EU). Source: own study based on FADN data. 
Proceedings of the 2018 International Scientific Conference 'Economic Sciences for Agribusiness and Rural Economy' No 2, Warsaw, 7-8 June 2018, pp. 144-153

Cypriot (7.2\%), Czech (4.5\%) and French farms $(1.2 \%)$. In other countries there was a decrease in labour outlays per 1 ha of UAA, the largest in Bulgarian farms (on average 7.1\%), Croatian (by -4.6\%), Greek (by $-4.2 \%$ ) and Italian (by $-2.9 \%$ ). In absolute terms, the largest increase in labour outlays per 1 ha of UAA was recorded in Romanian farms (on average annually by 0.32 AWU per 1 ha UAA) and Cypriot farms ( 0.15 ha AWU per 1 ha UAA), while the largest decrease in labour outlays per 1 ha UAA was observed on Bulgarian and Slovenian farms (after -0.10 AWU per 1 ha of UAA) and Greek (by -0.9 AWU per 1 ha of UAA).

In the years 2004-2015, the largest assets per 1 ha of UAA occurred on Croatian farms (on average EUR 54.8 thousand per 1 ha of UAA), Slovenian (EUR 46.1 thousand per 1 ha of UAA) and German (EUR 44.5 thousand per 1 ha of UAA) and Italian (EUR 42.5 thousand per 1 ha of UAA). In the analysed period, the largest relative increase in assets per 1 ha of UAA was in Czech farms (annual average of 14.5\%), Austrian (by 7.5\%) and Slovenian (by 5.6\%). In turn, the decrease in total assets per 1 ha of UAA was on Croatian farms (on average by $8.8 \%$ ), Romanian (by $-4.0 \%$ ) and German and Spanish (by $-0.3 \%$ ). In absolute terms, the largest increase in total assets per 1 ha of arable land was in Czech farms (by EUR 5.4 thousand per 1 ha of UAA), in Slovenian (by EUR 2.6 thousand per 1 ha of UAA) and in Italian (by EUR 1.1 thousand per 1 ha of UAA). The largest decline in absolute terms was recorded on Croatian farms (on average by EUR 4.8 thousand per 1 ha of UAA) and Romanian (by EUR 0.8 thousand per 1 ha of UAA).

In the surveyed years the Italian farms were characterized by the greatest technical equipment (about EUR 274.6 thousand/AWU on average), then German farms (approx. EUR 215.4 thousand/AWU), French farms (EUR 202.8 thousand/AWU) and Austrian (approx. EUR 190 thousand/AWU) - Figure 1. On the other hand, the smallest technical labour equipment was observed in Bulgarian farms (on average approx. EUR 54 thousand/AWU), Romanian (around approx. 55.1 thousand/AWU), and Portuguese (approx. EUR 75.8 thousand/AWU) and Greek (approx. EUR 84.7 thousand/AWU) and Hungarian (approx. EUR 85.6 thousand/AWU). In the analysed period, in relative terms, the largest increase in technical labour equipment was recorded in Czech (annual average of $10.1 \%$ ), Bulgarian (approx. 8.8\%), Slovenian (approx. $7.8 \%$ ) and Portuguese $(7.3 \%)$ farms. In absolute terms, the largest increase in technical labour equipment was recorded in Italian farms (on average annually by approx. EUR 14.9 thousand/AWU), Czech (by EUR 14.4 thousand/AWU) and Slovenian (by

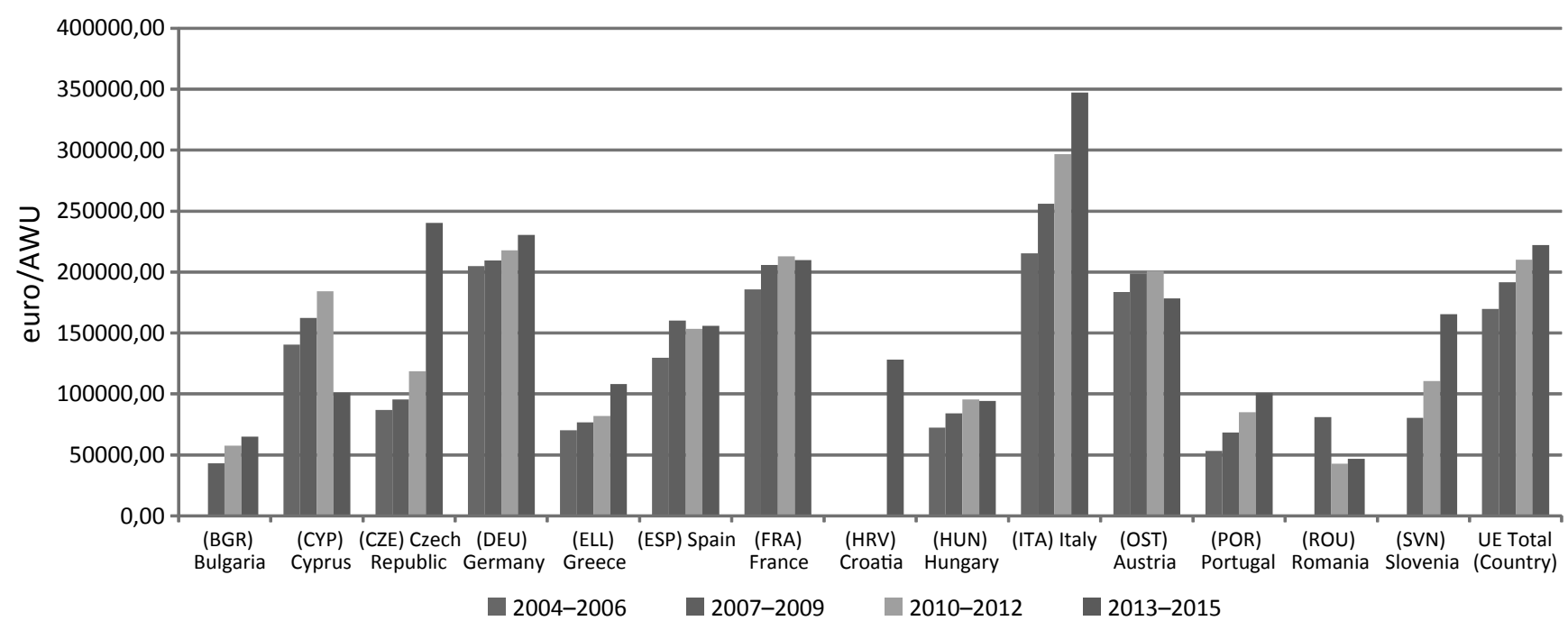

Figure 1. Technical equipment for work in specialist vineyards in the years 2004-2015 (\%) Source: own study based on FADN. 
Proceedings of the 2018 International Scientific Conference 'Economic Sciences for Agribusiness and Rural Economy' No 2, Warsaw, 7-8 June 2018, pp. 144-153

EUR 9.7 thousand/AWU). In the analysed period, the decrease in technical labour equipment was recorded in Croatian farms (on average by $4.2 \%$ ), Romanian (by $-3.4 \%$ ) and Cypriot (by $-3.3 \%$ ).

\section{TOTAL PRODUCTION COSTS}

In 2004-2015 on average in the EU countries the total costs in viticulture increased from approx. EUR 3.4 thousand per 1 ha of UAA to approx. EUR 4.2 thousand per 1 ha of UAA, i.e. by approx. $27.8 \%$. The average annual increase in total costs per 1 ha of UAA was almost $2.3 \%$. On average, in the analysed period, total costs per 1 ha of UAA amounted to approx. EUR 3.7 thousand per 1 ha of UAA (Table 2).

In the analysed period, the largest total costs per 1 ha of arable land in viticulture were on German farms (on average approx. EUR 8.4 thousand per 1 ha of
UAA), then on French farms (on average over EUR 6.5 thousand per 1 ha of UAA), on Czech farms (over EUR 6 thousand per 1 ha of UAA). The lowest total costs per 1 ha of arable land in viticulture were on Spanish farms (on average approx.. EUR 822.4 per 1 ha of UAA), then on Portuguese farms (on average over EUR 2 thousand per 1 ha of UAA), also on farms Romanian, Bulgarian (approx. EUR 2.5 thousand per 1 ha of UAA) and Cypriot (over EUR 2.6 thousand per 1 ha of UAA).

In the analysed period, the decrease in total costs per 1 ha of arable land in viticulture was recorded only on Bulgarian farms (on average by almost 1.5\%) and on Italian farms (on average by $0.34 \%$ ). In the other selected EU countries there was an increase in total costs per 1 ha of wine growing UAA. In relative terms, the largest increase in costs was on Czech farms (on average by $15.4 \%$ annually), then on Aus-

Table 2. Total input per 1 ha UAA in specialist vineyards in selected EU countries in 2004-2015

\begin{tabular}{|c|c|c|c|c|c|c|c|c|}
\hline \multirow[t]{2}{*}{ Specification } & \multirow[t]{2}{*}{ Country } & $\begin{array}{l}2004- \\
-2006\end{array}$ & $\begin{array}{l}2007- \\
-2009\end{array}$ & $\begin{array}{l}2010- \\
-2012\end{array}$ & $\begin{array}{l}2013- \\
-2015\end{array}$ & $\begin{array}{c}\text { Average } \\
2004-\end{array}$ & \multicolumn{2}{|c|}{$\begin{array}{c}\text { Average } \\
\text { annual change }\end{array}$} \\
\hline & & \multicolumn{6}{|c|}{ absolute values } & $\%$ \\
\hline \multirow{15}{*}{$\begin{array}{l}\text { Total input } \\
\text { per } 1 \text { ha UAA } \\
\text { (EUR) }\end{array}$} & (BGR) Bulgaria* & - & 2544.12 & 3163.59 & 2026.01 & 2577.91 & -65.70 & -1.48 \\
\hline & (CYP) Cyprus* & 1790.45 & 1887.15 & 2194.81 & 3936.89 & 2672.95 & 241.02 & 7.90 \\
\hline & (CZE) Czech Republic & 2146.21 & 3439.01 & 5306.14 & 9337.04 & 6027.39 & 775.53 & 15.41 \\
\hline & (DEU) Germany & 7760.73 & 8719.08 & 8145.63 & 8804.12 & 8556.27 & 81.40 & 1.00 \\
\hline & (ELL) Greece & 2391.40 & 2495.94 & 2529.99 & 2492.48 & 2506.14 & 16.12 & 0.68 \\
\hline & (ESP) Spain & 779.26 & 707.59 & 729.46 & 1030.15 & 822.40 & 26.01 & 2.86 \\
\hline & (FRA) France & 5274.10 & 6003.31 & 6569.85 & 7204.38 & 6592.51 & 212.43 & 3.43 \\
\hline & (HRV) Croatia* & - & - & - & 3726.38 & 3726.38 & 153.77 & 4.26 \\
\hline & (HUN) Hungary & 3535.92 & 3030.46 & 3689.79 & 3601.30 & 3440.52 & 34.36 & 1.05 \\
\hline & (ITA) Italy & 3476.87 & 3410.35 & 3485.41 & 3370.98 & 3422.25 & -12.16 & -0.34 \\
\hline & (OST) Austria & 2035.46 & 2831.06 & 3818.16 & 5085.49 & 3911.57 & 331.92 & 9.99 \\
\hline & (POR) Portugal & 1783.05 & 1805.50 & 2049.60 & 2476.88 & 2110.66 & 73.68 & 3.57 \\
\hline & (ROU) Romania* & - & 2688.89 & 2076.74 & 2904.29 & 2556.64 & 7.78 & 0.76 \\
\hline & (SVN) Slovenia* & 3852.87 & 3777.90 & 5342.08 & 5611.56 & 4910.52 & 260.74 & 5.73 \\
\hline & (EU) European Union & 3370.27 & 3458.63 & 3731.14 & 4129.77 & 3773.18 & 85.54 & 2.28 \\
\hline
\end{tabular}

Source: own study based on FADN data. 
Proceedings of the 2018 International Scientific Conference 'Economic Sciences for Agribusiness and Rural Economy' No 2, Warsaw, 7-8 June 2018, pp. 144-153

trian farms (on average by almost 10\%) and on Cypriot farms (on average by $7.9 \%$ per year). In absolute terms, the highest increase in total costs per 1 ha of UAA was also in Czech farms (on average by more than EUR 775.5 per 1 ha of UAA), Austrian (on average by EUR 331.9 per 1 ha of UAA), and Slovene (on average annually by over EUR 260.7 per 1 ha of UAA), Cypriots (on average annually by over EUR 241.0 per 1 ha of UAA) and French (on average annually by over EUR 212.4 per 1 ha of UAA).

\section{DIRECT PRODUCTION COSTS}

The direct costs of wine-growing production per 1 ha of arable land in EU countries amounted to an average of EUR 633.7 per 1 ha of UAA. In the analysed period, in relative terms, the increase in direct costs in the EU countries amounted to about $2.4 \%$ on average, while in absolute terms, direct costs increased on an annual basis by approx. EUR 15.3 per 1 ha of UAA. The largest direct costs per 1 ha of arable land were incurred on German farms (on average approx EUR 2.1 thousand per 1 ha of UAA), then on Slovenian farms (approx. EUR 1.1 thousand) and Czech farms (approx. EUR 917 per 1 ha of UAA), Croatian (over EUR 860 per 1 ha of UAA) and Italian (approx. EUR 842 per 1 ha of UAA). The lowest direct costs per 1 ha of arable land were incurred on Spanish farms (on average approx. EUR 161 per 1 ha of UAA), Cypriot (approx. EUR 354.4 per 1 ha of UAA) and Bulgarian (approx. EUR 428 per 1 ha of UAA).

In the analysed period almost in all countries surveyed there was an increase in direct costs per 1 ha of UAA, except for Italian farms (decrease on average by $2.1 \%$ ) and Greek (by $-1.4 \%$ ). The largest, in relative terms, increase in direct costs per 1 ha of UAA was in Czech farms (annual average of 11.1\%), Portuguese (by 10.3\%) and Austrian (by 9.5\%). In abso-

Table 3. Specific crops cost per 1 ha UAA in specialist vineyards in selected EU countries in 2004-2015

\begin{tabular}{|c|c|c|c|c|c|c|c|c|}
\hline \multirow[t]{2}{*}{ Specification } & \multirow[t]{2}{*}{ Country } & $\begin{array}{l}2004- \\
-2006\end{array}$ & $\begin{array}{l}2007- \\
-2009\end{array}$ & $\begin{array}{l}2010- \\
-2012\end{array}$ & $\begin{array}{l}2013- \\
-2015\end{array}$ & $\begin{array}{c}\text { Average } \\
2004- \\
-2015\end{array}$ & \multicolumn{2}{|c|}{$\begin{array}{l}\text { Average annual } \\
\text { change }\end{array}$} \\
\hline & & \multicolumn{6}{|c|}{ absolute values } & $\%$ \\
\hline \multirow{15}{*}{$\begin{array}{l}\text { Direct costs } \\
\text { per } 1 \text { ha } \\
(\text { EUR) }\end{array}$} & (BGR) Bulgaria* & - & 278.57 & 650.85 & 353.86 & 427.76 & 0.27 & 1.71 \\
\hline & (CYP) Cyprus* & 291.12 & 317.69 & 396.03 & 412.65 & 354.37 & 15.57 & 4.38 \\
\hline & (CZE) Czech Republic & 541.09 & 626.51 & 959.92 & 1539.52 & 916.76 & 104.65 & 11.11 \\
\hline & (DEU) Germany & 1933.94 & 2259.67 & 2065.02 & 2224.56 & 2120.80 & 21.91 & 1.09 \\
\hline & (ELL) Greece & 744.00 & 744.16 & 703.95 & 644.43 & 709.14 & -9.89 & -1.43 \\
\hline & (ESP) Spain & 156.13 & 136.92 & 137.03 & 213.29 & 160.84 & 5.84 & 3.12 \\
\hline & (FRA) France & 583.36 & 715.46 & 769.87 & 914.24 & 745.73 & 35.09 & 4.74 \\
\hline & (HRV) Croatia* & - & - & - & 860.01 & 860.01 & 52.91 & 6.44 \\
\hline & (HUN) Hungary & 399.55 & 878.34 & 979.67 & 649.76 & 726.83 & 32.60 & 5.74 \\
\hline & (ITA) Italy & 992.88 & 796.73 & 748.43 & 831.77 & 842.45 & -19.35 & -2.13 \\
\hline & (OST) Austria & 380.49 & 497.63 & 622.69 & 912.15 & 603.24 & 57.21 & 9.45 \\
\hline & (POR) Portugal & 296.76 & 465.90 & 620.78 & 770.30 & 538.43 & 51.22 & 10.28 \\
\hline & (ROU) Romania* & - & 416.14 & 593.17 & 697.65 & 568.99 & 49.38 & 7.52 \\
\hline & (SVN) Slovenia* & 987.96 & 907.11 & 1213.85 & 1200.29 & 1085.42 & 38.67 & 4.01 \\
\hline & (EU) European Union & 576.52 & 580.65 & 620.10 & 717.68 & 623.74 & 15.26 & 2.37 \\
\hline
\end{tabular}

Source: own study based on FADN data. 
Proceedings of the 2018 International Scientific Conference 'Economic Sciences for Agribusiness and Rural Economy' No 2, Warsaw, 7-8 June 2018, pp. 144-153

lute terms, the largest increase in total direct costs per 1 ha of UAA was also on Czech farms (on average annually by over EUR 104.6 per 1 ha of UAA) and on Austrian farms (approx. EUR 57.2 per 1 ha of UAA), Croatian (by EUR 52.9 per 1 ha of UAA) and Portuguese (EUR 51.2 per 1 ha of UAA). In absolute terms, the decline in direct costs per 1 ha of UAA on Italian farms was approx. EUR 19.4 per 1 ha of UAA and on Greek farms by approx. EUR 9.9 per 1 ha of UAA.

\section{INDIRECT COSTS OF PRODUCTION}

In the years 2004-2015, the average indirect costs per 1 ha of UAA in the EU countries amounted to approx. EUR 3.1 thousand per 1 ha of UAA. In the analysed period, in EU countries a relative increase in indirect costs per 1 ha of UAA was observed on an average annual basis by approx. $2 \%$, while in absolute terms, the average annual growth was about EUR 62.2 per
1 ha of UAA. The highest indirect costs per 1 ha of UAA in the analysed period were in German farms (on average approx. EUR 6.3 thousand per 1 ha of UAA), then French (approx. EUR 5.8 thousand per 1 ha of UAA) and Czech farms (approx. EUR 4.2 thousand per 1 ha of UAA). While the lowest indirect costs per 1 ha of UAA were on Spanish farms (on average approx. EUR 657.3 per 1 ha of UAA), Portuguese (approx. EUR 1,488.7 per 1 ha of UAA) and Romanian (approx. EUR 1,982.3 per 1 ha of UAA). In relative terms, the largest increase in indirect costs per 1 ha of UAA was recorded in Czech holdings (on average by approx. 14.2\%), Austrian (by 9.1\%), Cypriot (by $8.3 \%$ ) and Slovenian (by 6.0\%). A drop in indirect costs was recorded in Romanian (on average by $-1.0 \%$ ), Italian (by $-0.5 \%$ ), Bulgarian (by $-0.5 \%$ ) and Hungarian (by $-0.3 \%$ ). Total indirect costs per 1 ha in specialist vineyards in selected EU countries are presented in Table 4.

Table 4. Indirect costs per 1 ha in specialist vineyards in selected EU countries in the years 2004-2015

\begin{tabular}{|c|c|c|c|c|c|c|c|c|}
\hline \multirow[t]{2}{*}{ Specification } & \multirow[t]{2}{*}{ Country } & $\begin{array}{l}2004- \\
-2006\end{array}$ & $\begin{array}{l}2007- \\
-2009\end{array}$ & $\begin{array}{l}2010- \\
-2012\end{array}$ & $\begin{array}{l}2013- \\
-2015\end{array}$ & $\begin{array}{l}\text { Average } \\
2004- \\
-2015\end{array}$ & \multicolumn{2}{|c|}{$\begin{array}{c}\text { Average } \\
\text { annual change }\end{array}$} \\
\hline & & \multicolumn{6}{|c|}{ absolute values } & $\%$ \\
\hline \multirow{15}{*}{$\begin{array}{l}\text { Indirect costs } \\
\text { per } 1 \text { ha } \\
\text { (EUR) }\end{array}$} & (BGR) Bulgaria* & - & 1825.25 & 2512.66 & 1671.51 & 2003.14 & -21.84 & -0.49 \\
\hline & (CYP) Cyprus* & 1499.22 & 1569.69 & 1798.51 & 3501.77 & 2289.99 & 223.20 & 8.32 \\
\hline & (CZE) Czech Republic & 1501.42 & 2796.58 & 4345.23 & 5617.53 & 4253.11 & 452.63 & 14.20 \\
\hline & (DEU) Germany & 5819.19 & 6451.56 & 6075.68 & 6472.38 & 6333.21 & 49.09 & 0.81 \\
\hline & (ELL) Greece & 1643.64 & 1745.97 & 1819.47 & 1830.97 & 1798.80 & 24.97 & 1.47 \\
\hline & (ESP) Spain & 622.97 & 570.41 & 592.42 & 809.12 & 657.31 & 19.32 & 2.70 \\
\hline & (FRA) France & 4682.85 & 5282.90 & 5796.26 & 6259.28 & 5779.48 & 174.94 & 3.22 \\
\hline & (HRV) Croatia* & - & - & - & 2783.88 & 2783.88 & 78.07 & 2.87 \\
\hline & (HUN) Hungary & 3134.83 & 2151.87 & 2709.95 & 2812.05 & 2557.96 & -13.42 & -0.29 \\
\hline & (ITA) Italy & 2465.88 & 2603.38 & 2716.59 & 2349.02 & 2556.33 & -11.64 & -0.50 \\
\hline & (OST) Austria & 1646.30 & 2321.93 & 3188.31 & 3816.73 & 3108.99 & 238.39 & 9.13 \\
\hline & (POR) Portugal & 1481.50 & 1334.48 & 1426.82 & 1704.85 & 1488.72 & 22.86 & 1.52 \\
\hline & (ROU) Romania* & - & 2271.97 & 1481.32 & 2193.67 & 1982.32 & -43.69 & -1.04 \\
\hline & $(\mathrm{SVN})$ Slovenia* & 2848.54 & 2814.74 & 4089.58 & 4281.92 & 3728.75 & 208.40 & 6.02 \\
\hline & (EU) European Union & 2785.67 & 2867.55 & 3103.84 & 3329.33 & 3100.24 & 62.22 & 2.03 \\
\hline
\end{tabular}

Source: own study based on FADN. 
Proceedings of the 2018 International Scientific Conference 'Economic Sciences for Agribusiness and Rural Economy' No 2, Warsaw, 7-8 June 2018, pp. 144-153

\section{THE SHARE OF DIRECT AND INDIRECT COSTS OF PRODUCTION}

In the viticulture in selected EU countries, the share of indirect costs in total costs (per 1 ha of arable land) was high (Fig. 2). In the analysed period, the highest share of indirect costs in total costs was on French farms (on average around 87.7\%), then on Cypriot (84.3\%), Spanish (80.2\%) and Austrian (80.0\%) farms. On the other hand, the smallest share of indirect costs was in Portuguese farms (on average around 70.8\%), Greek (71.7\%), Hungarian (74.4\%) and Italian (74.7\%). In the analysed period, the decrease in the share of indirect costs in total costs (per 1 ha of UAA) was recorded in Romanian farms (by 24.0 p.p.), Czech (by 21.0 p.p.), Austrian (by 13.7 p.p.), Portuguese (by 9.2 p.p.) and Italian (by 4.9 p.p.). On the other hand, the increase in the share of indirect costs in total costs was recorded only in Cypriot (7.3 p.p.), Greek (4.3 p.p.) and Hungarian ( 0.3 p.p.) farms.

In the years 2004-2015, the share of direct costs in total costs in farms specializing in viticulture in selected EU countries was relatively low. The share of direct costs in total costs was on average around $17.7 \%$. The highest share of direct costs was in Portuguese farms (on average 29.2\%), Greek (28.3\%), Hungarian (25.6\%) and Italian (25.3\%). The smallest share of direct costs in total costs was on French farms (approx. 12.3\% on average), Cypriot (15.7\%), Spanish (19.8\%) and Austrian farms (20.0\%).

\section{CONCLUSIONS}

Based on the conducted analysis the following conclusions could be drawn:

- The wine sector plays an important role in many European national economies, especially in areas with favourable conditions for vine growing. In the years 2004-2015, in the surveyed vine farms, there was a large variation in terms of the structure of production costs.

- In the analysed period, the largest total costs per 1 ha of arable land were noticed on German, then French and Czech farms, while the lowest on Romanian, Bulgarian and Cypriot farms. In the analysed period, the majority of countries recorded an increase in total costs per 1 ha of UAA, except for Bulgarian farms.

- The largest direct costs per 1 ha were incurred on German, Slovenian and Czech, farms, while the smallest on Spanish, Cypriot and Bulgarian. In the analysed period almost in all surveyed countries there was an increase in direct costs per 1 ha of UAA, except for Italian and Greek holdings. In

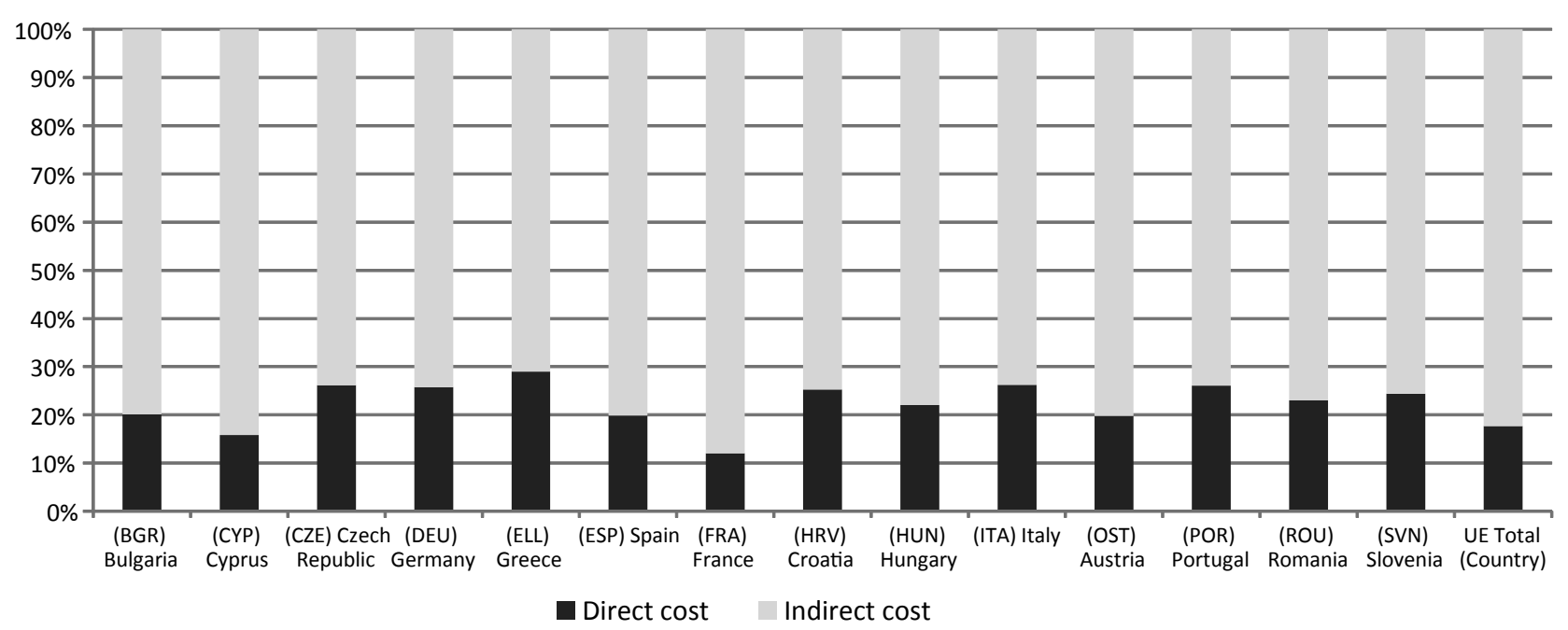

Figure 2. Share of direct and indirect costs per 1 ha of UAA in total inputs in specialist vineyards in the years 2004$-2015(\%)$

Source: own study based on FADN. 
direct costs, plant protection had the largest share, followed by fertilization costs, while the lowest were the costs of pruning.

- The share of indirect costs in total costs in the cultivation of vines in selected countries was relatively high. In the analysed period, the highest share of indirect costs in total costs was on Cypriot, Austrian and Spanish farms, while the lowest was on Czech, Portuguese and Italian.

\section{Acknowledgements}

This paper is based on the results of the project VITISMART (Toward a sustainable viticulture: Improved grapevine productivity and tolerance to abiotic and biotic stresses by combining resistant cultivars and beneficial microorganisms). The financing of this project by ERA-NET CO-FUND FACCE SURPLUS program through Polish National Centre for Research and Development (NCBiR) is acknowledged.

\section{REFERENCES}

1. Delord, B., Montaigne, E., Coelho, A. (2015). Vine planting rights, farm size and economic performance: Do economies of scale matter in the French viticulture sector?. Wine Economics and Policy, 1 (1), pp. 22-34

2. Filipiak, T., Maciejczak, M. (2018). Competitiveness of specialist vineyards in selected European Union countries in the years 2004-2015. In: Proceedings of the International Conference 'Economic science for rural development', LLU, Jelgava, Latvia, 09-11.05.2018.

3. Goraj, L., Mańko, S. (2004). Systemy monitorowania sytuacji ekonomicznej i produkcyjnej gospo- darstw rolnych [Systems of monitoring of economic and production situation of agricultural holdings]. In: Rachunkowość rolnicza [Agricultural accounting]. Difin, Warsaw, pp. 45-50.

4. Kondraszuk, T. (2012). Rachunek kosztów w rolnictwie na tle ogólnej teorii ekonomiki przedsiębiorstw ze szczególnym uwzględnieniem kosztów bezpośrednich i zmiennych [The account of costs in agriculture on the backgroung of generat theory of economics with special emphasis on direct and variable costs]. Prace Naukowe UE we Wrocławiu, 251, pp. 294-305.

5. Latruffe, L. (2010). Competitiveness. Productivity and efficiency in the agricultural and agri-food sectors. OECD Food, Agriculture and Fisheries Papers, 30, pp. 234-245.

6. Maciejczak, M. (2017). Innovations in viticultural production in Poland under climate change conditions. Annals of the Polish Association of Agricultural and Agribusiness Economists SERiA, 19 (2), pp. 151-157.

7. Sgroi, F., Di Trapani, A.M., Testa, R., Tudisca, S. (2014). Strategy to increase the farm competitivesess. American Journal of Agricultural and Biological Sciences, 9 (3), pp. 384-400.

8. Sobczyński, T., Stefko, O. (2011). Zmiany rentowności gospodarstw ogrodniczych w Polsce i UE [Changes of rentability of horticultural farms in Poland and in the EU]. Zagadnienia Ekonomiki Rolnej, 4, pp. 139-153.

9. Toth, J., Vegvari, Z. (2015). Future of winegrape growing regions in Europe. Australian Journal of Grape and Wine Research, 22 (1), pp. 64-72.

10. Umbreziova, I., Hrda, V. (2014). Evaluation of competitiveness of viticulture and viniculture in Sloavkia. In: Proceedings of 13th International Conference 'Improving performance of agriculture and the economy'. Slovak University of Agriculture, 21-23.05.2014, Nitra, pp. 409-417. 